\title{
Oitenta anos de Divinis redemptoris: A consolidação do anticomunismo católico
}

DOI: 10.15175/1984-2503-201810304

Haneron Victor Marcos*

\section{Resumo}

Este trabalho apresenta uma leitura crítica da Carta Encíclica Divinis redemptoris, do pontificado de Pio XI, de 1937, na marca de seus oitenta anos de existência, que consolidou as razões do anticomunismo católico. Situa-se metodologicamente no âmbito dos estudos de História das ideias políticas. Analisamos os itens da divisão temática da encíclica: I. Atitude da Igreja perante o comunismo; II. Doutrina e frutos do comunismo; III. Luminosa doutrina da Igreja, oposta ao comunismo; IV. Remédios e meios; V. Ministros e auxiliares desta obra social da Igreja. Ambientada num comunismo bolchevique de tutela stalinista, com influências destacadas - pela própria Carta - na Rússia, México e Espanha, ela segue como representativa do anticomunismo católico na contemporaneidade, implicando efeitos que vão além dos limites da Santa Sé.

Palavras-chave: Comunismo; Divinis redemptoris; anticomunismo católico; conservadorismo clerical; Santa Sé.

\section{Ochenta años de Divinis redemptoris: la consolidación del anticomunismo católico}

\section{Resumen}

Este trabajo presenta una lectura crítica de la Carta Encíclica Divinis redemptoris, del pontificado de Pío XI, de 1937, en la marca de sus ochenta años de existencia, que consolidó las razones del anticomunismo católico. Se sitúa metodológicamente en el marco de los estudios de historia de las ideas políticas. Analizamos los elementos de la división temática de la encíclica: I. Posición de la Iglesia frente al comunismo; II. Doctrina y frutos del comunismo; III. Opuesta y luminosa doctrina de la Iglesia; IV. Remedios y medios; V. Ministros y auxiliares de esta obra social de la Iglesia. Ambientada en un comunismo bolchevique de tutela estalinista, con influencias destacadas - por la propia carta - en Rusia, México y España, sigue siendo representativa del anticomunismo católico en el mundo contemporáneo, con efectos implícitos que van más allá de los límites de la Santa Sede.

Palabras clave: Comunismo; Divinis redemptoris; anticomunismo católico; conservadurismo clerical; Santa Sede.

Eighty years of Divini Redemptoris: The consolidation of Catholic anti-communism

Abstract:

The following work serves as a critical reading of Pope Pius XI's 1937 Encyclical Letter Divini Redemptoris in light of its 80th anniversary, consolidating as it did the reasons behind Catholic anti-communism. In methodological terms, the letter is located in the sphere of study concerned with the history of political ideas. We analyze the items in the circular's thematic division: I. The Church's attitude to communism; II. Doctrine and fruits of communism; III. The Church's luminous doctrine, opposed to communism; IV. Remedies and means; V. The Church's ministers and assistants employed in this social initiative. Rooted in Bolshevik communism of a Stalinist slant with prominent influences - by means of the letter itself - in Russia, Mexico, and Spain, it remains as a contemporary representative of Catholic anti-communism, implying effects beyond the limits of the Holy See.

Keywords: Communism; Divini Redemptoris; Catholic anti-communism; clerical conservatism, the Holy See.

\footnotetext{
* Doutorando em Direito pela Universidade de Buenos Aires. Bacharel em Direito pela Universidade do Vale do Itajaí e Mastére Spécialisé em Gestão e Inovação pela École Nationale Supérieure des Mines de SaintÉtienne - EMSE, 2010. E-mail: haneron@casan.com.br. Orcid ID: https://orcid.org/0000-0003-2299-4694
} 
Les quatre-vingts ans du Divinis redemptoris : la consolidation de l'anticommunisme catholique Résumé

Cet article propose une lecture critique de l'Encyclique Divinis redemptoris, publiée en 1937 sous le pontificat de Pie XI, qui fête donc ses 80 ans et peut être considérée comme l'un des piliers de l'anticommunisme catholique. Pour ce qui est de la méthodologie adoptée, nous nous situons dans le cadre de l'histoire des idées politiques. Nous analyserons les divers éléments de la division thématique de l'encyclique : I. Attitude de l'église en face du communisme ; II. Doctrine et fruits du communisme ; III. La lumineuse doctrine de l'Église ; IV. Remèdes et moyens ; V. Ministres et auxiliaires de cette œuvre sociale de l'Église. Située dans le contexte d'un communisme bolchevique sous la férule de Staline, avec des influences - soulignées dans l'encyclique elle-même - en Russie, au Mexique et en Espagne, cette encyclique est jusqu'aujourd'hui fort représentative d'un anticommunisme catholique dont les effets se font sentir bien au-delà des limites du Saint-Siège.

Mots-clés : communisme ; Divinis redemptoris ; anticommunisme catholique ; conservatisme clérical ; SaintSiège.

\section{存在了八十年的教皇神圣救赎通谕：天主教反共主义的确立与巩固}

\section{摘要}

本文介绍了教皇庇佑十一世于 1937 年发布的通谕一神圣救赎(Divinis redemptoris)并且对其进行了批判性解读。 此通谕从发布日至今已经有 80 年, 它巩固了天主教的反共的思想与行为。我们使用政治思想史研究方法, 分 析了通谕主要议题：(I) 教会对共产主义的态度；(II) 教会所理解的共产主义的学说和后果；(III) 教会反共, 启 蒙救世学说；(IV) 补救措施和手段；(V) 教会对这项社会工作的领导和协助。天主教会面对在斯大林的指导下 的布尔什维克共产主义, 及其在俄罗斯, 墨西哥和西班牙所具有的广泛的影响, 理所当然的挑起了反共大旗并 成为当今时代的天主教反共产主义的代表, 这种行为的影响力超出了罗马教廷的范围。

关键词：共产主义；神圣救赎 (Divinis redemptoris) ; 天主教的反共产主义；神职人员的保守主义；罗马教廷。

O dia 19 de março de 2017 marcou a passagem de oito décadas da edição da Carta Encíclica Divinis redemptoris, pela Santa Sé, então conduzida pelo Papa Pio XI. Ela representava uma consolidação das razões anticomunistas da Igreja Católica, num atribulado ambiente mundial impactado, no que toca ao tema, dentre outras coisas, pela Guerra Civil Espanhola, pelas notícias de expurgos do regime comunista soviético, assim como pelo impetuoso trabalho da Internacional Comunista fomentando células revolucionárias em todo o orbe, como no Brasil criaria corpo com o Levante Comunista de 1935.

Não era a primeira investida católica oficial contra o comunismo. Cita-se como primeira referência formal representativa a Encíclica Qui pluribus, de 1846, na qual Pio IX já advertia seus fiéis sobre essa doutrina, que se opondo à lei natural, "destruiria completamente os direitos do homem, suas propriedades e fortuna, e até a própria

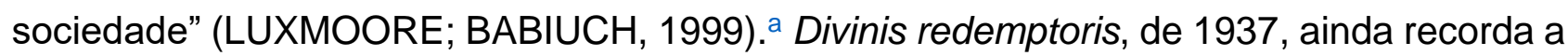
Encíclica de Leão XIII (Quod Apostolici muneris, de 1878), que a qualificava de "peste mortífera, que invade a medula da sociedade humana e a conduz a um perigo extremo". 
Essas "circulares" da Igreja assumiam enorme impacto num momento histórico em que os canais informativos eram escassos, e a ramificação católica permitia a disseminação de conceitos centralmente construídos aos mais longínquos rincões. A estigmatização referenciando o comunismo em oposição às leis divinas é, portanto, uma prática secular, como por exemplo aquela construída a partir de relatórios oficiais sobre os revolucionários mortos na Comuna de Paris, de 1871, que expressavam sobre rostos distorcidos, como decorrentes de uma possessão. O anticomunismo católico foi, enfim, fonte crucial de nutrição das correntes de direita e do fascismo ao longo da história, com impacto direto na democracia representativa e até mesmo na produção legislativa decorrente.

Em 1937, Pio XI (1937, “Introdução”, par. 3)a deixa expresso, já na introdução de sua Carta, que o comunismo que está a referenciar é aquele denominado "bolchevista e ateu, que se propõe como fim peculiar revolucionar radicalmente a ordem social e subverter os próprios fundamentos da civilização cristã". A Revolução Russa e a consectária materialização do marxismo de interpretação leninista pelo PCUS, exportada pela Terceira Internacional, passam a ser referências de combate, como fenômeno que escapara da retórica e dos círculos dialéticos do socialismo e do comunismo europeus ocidentais.

Naquele momento histórico, entendia a Sé Apostólica pela necessidade de um novo documento solene, ratificador das condenações passadas, para se contrapor ao materialismo dialético e histórico marxista de interpretação bolchevique que ferozmente atacava os predeterminismos do catolicismo, secular justificador de ilimitados poderes monárquicos. Para cumprimento desse desiderato e o alcance de uma conclusão, Divinis redemptoris é dividida em cinco capítulos, a saber: I. Atitude da Igreja perante o comunismo; II. Doutrina e frutos do comunismo; III. Luminosa doutrina da Igreja, oposta ao comunismo; IV. Remédios e meios; V. Ministros e auxiliares desta obra social da Igreja. Essa será, pois, a divisão do presente trabalho.

\section{Atitude da Igreja perante o comunismo}

Como antecipado, não havia novidade na condenação católica ao comunismo. Após as encíclicas de 1846 e de 1878, de Pio IX e Leão XIII, respectivamente, Pio XI apresenta toda a fartura de seu pontificado nesse mister. Foram cinco encíclicas em que, com base em experiências na Rússia, México e Espanha, se ergueu a voz contra o comunismo: Miserentissimus Redemptor (1928); Quadragesimo anno (1931); Caritate Christi (1932); Acerba animi (1932); e Dilectissima Nobis (1933). 
A proposta era de um novo documento solene e consolidante, expedido pela Sé Apostólica ("mestra da verdade"), que sintetizasse "os sofismas teóricos e práticos do comunismo", para salvaguardar a sociedade cristã desse "horrendo flagelo", principalmente focado na ação do bolchevismo (PIO XI, 1937, "Necessidade de um novo...", par. 7). ${ }^{\text {b }}$

As institucionalizações sociais dos sentidos negativos e pejorativos sobre o tema têm na Igreja uma referência embrionária. Se a Santa Sé se referia "a ideias subversivas [que] ameaçam invadir rapidamente os outros países do mundo" (PIO XI, 1937, "Necessidade de um novo...", par. 6), ${ }^{\circ}$ não era difícil prever uma dramática e negativa sedimentação conceitual também nas oposições políticas e na imprensa de situação. Não raro, e consectário desse labor retórico sistematizado, era encontrar matérias jornalísticas que apelavam à estigmatização associada com a religião para o afugentamento popular das siglas comunistas, como se exemplifica a partir do jornal brasileiro "O Paiz" de 1930:

O comunismo é o roubo da propriedade, a dissolução da família, a servidão do povo, a destruição da pátria. Não há religião, não há lar, não há nação dentro dos princípios, das doutrinas e das práticas do bolchevismo. A ideia de Deus desaparece (MARIANI, 1998, p. 155). ${ }^{\text {a }}$

Instaura-se uma narratividade que passava uma ilusão de consenso. Acerta Marco Pereira (2009, p. 17, grifo do autor) ${ }^{a}$ que "muito além de uma manifestação espontânea, o anticomunismo pertence a um discurso da ordem extremamente elaborado, fundamentado, organizado e difundido pela Igreja". E, por conseguinte, para as grandes massas não tocadas por uma mínima instrução educacional, política ou sindical, a sedimentação da associação entre o comunismo e um ateísmo adepto do caos social, como um verdadeiro inferno terrestre que repulsa a Igreja e todos os seus princípios, era suficientemente digerível. O "genuíno progresso da humanidade" (PIO XI, 1937, "Necessidade de um

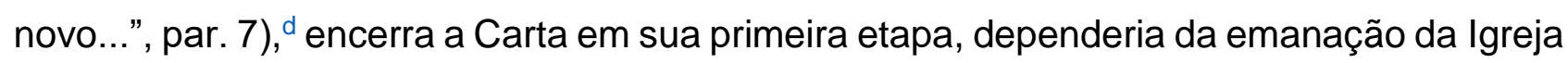
Católica, guardadora e reveladora dos preceitos divinos, insociável com a doutrina comunista. Ainda que ambas pregassem a "divisão dos pães", divergia-se quanto aos créditos e ao mérito do gesto, bem como aos seus limites e meios.

\section{Doutrina e frutos do comunismo}

Nessa nova Carta era preciso combater as raízes dessa doutrina que, segundo ela, era incompatível com a ideia de um Deus apaziguador, civilizador, garantidor, definidor e até então ordenador (pelos exemplos ou pelo temor reverencial num plano de vida eterna), quando pelo materialismo dialético e histórico a realidade e a justiça social eram determinadas pela dinamicidade das relações ambientais e materiais, o que confluía para 
a relação ou o embate entre classes (que deveriam ser extintas) e os modos e meios de produção. Não havia, pois, espaço para respostas espirituais, que justificaram por séculos o desigual e injusto estado das coisas.

E quanto a isso não se estava a tratar somente da escala "monarca vs. súdito" ou "indústria vs. operário", mas de toda a estratificação social, alcançando o pátrio poder e a instituição do casamento, por exemplo, motivo pelo qual também se ataca - e a história revelaria o caráter retrógrado de tal ato - a emancipação da mulher e a solubilidade do matrimônio. Com a flexibilização de tudo o que de mais sagrado considerava a Igreja, e aí se inclui em destaque a propriedade, firme consolidavam nessa nova Carta a pretensão comunista de "uma humanidade que tenha expulsado a Deus da terra" (PIO XI, 1937, "Em que se converteria...", par. 12, grifo do autor). ${ }^{\mathrm{e}}$

Reconhecem, sem embargo, que não só o liberalismo preparou caminho ao comunismo, mas a omissão da Igreja, ainda que tenham se olvidado que esse afastamento não se deva somente a uma questão de posicionamento territorial, mas na falta de um ativismo que avançasse contra os abusos da economia liberal, que não se coadunavam com os princípios do catolicismo.

Para sua própria proteção, posicionaram-se por muito tempo ao lado dos exploradores, e isso não seria esquecido pelos explorados, quando no poder. Daí a dedicação em protestar - e aí com justiça - contra os excessos praticados contra representantes eclesiásticos (com destaque para Rússia, México e Espanha), quando muitos sequer guardavam sintonia com o núcleo de poder político da Santa Sé, e pregavam princípios cristãos bastante similares, quando não idênticos, aos princípios socialistas e comunistas.

Não se estava diante de um texto conciliador, mas de restabelecimento de antagonismos:

\begin{abstract}
É este o espetáculo que atualmente com suma dor contemplamos: pela primeira vez na história estamos assistindo a uma insurreição, cuidadosamente preparada e calculadamente dirigida contra "tudo o que se chama Deus" (Cfr. 2 Tess 1, 4). Efetivamente, o comunismo opõe-se a qualquer religião, e a razão por que a considera como o "ópio do povo", é porque os seus dogmas e preceitos, pregando a vida eterna depois desta vida mortal, apartam os homens da realização daquele futuro paraíso, que são obrigados a conseguir na terra (PIO XI, 1937, "Luta contra tudo...", par. 22, grifo do autor). ${ }^{\dagger}$
\end{abstract}

Quando Marx sentencia a religião como elemento de entorpecimento do povo, o faz, assim se interpreta, não como impeditivo a qualquer espiritualidade apaziguadora, mas em crítica ao predeterminismo social fundado num interesse divino ou numa "Lei Natural Cristã" $($ TROELTSCH, 1931, p. 32)a que favorecia a perpetuação do ciclo de exploração. Não se é 
pobre e explorado por uma determinada expiação divina, tampouco o monarca se perpetua como explorador por essa condição.

Do paradigmático berço da revolução comunista, a Rússia, reconhecem, mesmo com eufemismo, os séculos de "inércia" aos quais foram acometidos milhões de trabalhadores explorados por uma longa casta bem-sucedida de czares:

\begin{abstract}
Não negamos que esses esforços na Rússia contribuíram não pouco para sacudir os homens e as suas instituições daquela longa e secular inércia em que jaziam, e que puderam, empregando todos os meios e processos; ainda mesmo ilegitimamente, fazer alguma coisa para promover o progresso material; mas sabemos por testemunhos absolutamente insuspeitos, e alguns bem recentes ainda, que de fato nem sequer neste ponto se conseguiu o que tanto se prometera (PIO XI, 1937, "O terrorismo", par. 23).9
\end{abstract}

Ignora a Carta, que com viés político prenuncia que os desígnios econômicos dos comunistas "também no futuro jamais o poderão conseguir" (PIO XI, 1937, "O terrorismo", par. 23), ${ }^{\text {h }}$ que 1937 representava duas décadas de revolução seguintes a séculos de imperialismo. Isso não passaria impune. A refração a um novo modelo econômico calcado no coletivismo, acompanhado de um ambiente de intensas guerras civis, de tentativas de invasão por outros países e de pós-guerra (Primeira Guerra Mundial), não tornavam lídimas tais sentenças.

\title{
Doutrina da Igreja, oposta ao comunismo
}

As sentenças guardavam um propósito: era momento de reafirmar que a salvação seria revelada unicamente pela "Mestra dos povos" (PIO XI, 1937, "III - Luminosa...", par. 25, grifo do autor), a Igreja. Reafirma, com propósito, que "o homem tem uma alma espiritual e imortal" (PIO XI, 1937, "Que são o homem...", par. 27), ’ o que explica o sentido de pacificação social apregoado pela doutrina católica, mas que também explica a subserviência pacífica de tempos imemoriais na expectativa dessa imortalidade através da ressurreição em fortuna àqueles obedientes à mesma.

O propósito desse capítulo é enunciar como a doutrina católica embrenha-se no "mundo dos homens" (indivíduo, sociedade, ordem econômico-social, hierarquia social e prerrogativas do Estado) e o expande sem finitude, em contraposição às frias expectativas dialéticas e históricas do materialismo que fundamentam o comunismo bolchevique, "ameaça" de então. Afinal, nada mais antagônico do que dispor que Deus dotara Jesus Cristo de múltiplas e variadas prerrogativas, tais como: "direito à vida, à integridade do corpo, aos meios necessários à existência; direito de tender ao seu último fim, pelo caminho traçado por Deus; direito enfim de associação, de propriedade particular e de usar dessa 
propriedade" (PIO XI, 1937, "Que são o homem...", par. 27). ${ }^{k}$ Mas o antagonismo não residia axialmente na existência de uma entidade espiritual e superior que apregoasse, em suas escritas, os mesmos objetivos de justiça social almejados pela revolução comunista. Muitos cidadãos soviéticos mantinham sua espiritualidade sem diminuir a crença em seus novos "deuses" marxistas. Residia, sim, na não aceitação de um sincretismo com essa nova força social, na libertação do homem contra o homem sem observância do "cronograma" da Santa Sé, que afastou da rebelião por muitos séculos os famintos (não só de comida, mas por liberdade de desígnios) contra aqueles monarcas por ela respaldados. A insistência, no contexto da pacificação social, de que "para assegurar esta tranquila harmonia pela colaboração orgânica de todos, a doutrina católica confere aos governantes tanta dignidade e autoridade" (PIO XI, 1937, "Hierarquia social...", par. 33) representava uma cruzada contra os governos populares que não obtivessem a chancela da Sé Apostólica, afastando assim forças que deveriam ser harmônicas, se fiéis - ambos os lados - à essência de sua doutrina de origem. Muito fácil, por sinal e exemplo, ver o comunismo no Sermão da Montanha.

Reconhece a Carta que também a Igreja - também, porque Marx e Engels não avançaram nesse sentido - não esquadrinhou profundamente uma burocracia estatal sobre a qual indefectivelmente se encaixariam os princípios de sua doutrina:

E assim, até mesmo no campo econômico-social, a igreja, muito embora não tenha
jamais apresentado como seu um determinado sistema técnico, por não ser essa a
sua missão, fixou, contudo, claramente princípios e diretivas que, prestando-se a
diversas aplicações concretas segundo as várias condições dos tempos, dos
lugares e dos povos, assinalam o caminho seguro para obter o feliz progresso da
sociedade (PIO XI, 1937, "Beleza desta doutrina...., par. 34). ${ }^{\mathrm{m}}$

Não considera, no entanto, ser momento para autocrítica sobre as falhas históricas de interpretação que resultaram em práticas de efeitos funestos, a mesma autocrítica que deveria - e posteriormente foi feita, ainda que se questione sua completude - ser aplicada sobre o marxismo-leninismo vigente em 1937. O antagonismo mais uma vez se mostrava não frente aos princípios cristãos, mas com a administração de interesses da Sé Apostólica resultantes da interpretação dos mesmos na hierarquização social, nomeadamente a estatal. Tanto que, contraditoriamente aos seus próprios princípios embrionários, considera que "erram vergonhosamente os que sem consideração atribuem a todos os homens direitos iguais na sociedade civil" (PIO XI, 1937, "Hierarquia social...", par. 33). ${ }^{n}$

Não só o socialismo e o comunismo encontram-se excomungados. É momento de a Carta expressar um inimigo, ao menos no plano retórico, em comum: o liberalismo. Guarda certa razão, por conseguinte, ao vaticinar que: 
não haveria nem socialismo nem comunismo, se os que governam os povos não tivessem desprezado os ensinamentos e as maternais advertências da Igreja; eles, porém, quiseram, sobre as bases do liberalismo e do laicismo, levantar outros edifícios sociais que à primeira vista pareciam poderosas e magníficas construções, mas bem depressa se viu que careciam de sólidos fundamentos, e se vão miseravelmente desmoronando, um após outro, como tem que desmoronar-se tudo quanto não se apoia sobre a única pedra angular, que é Jesus Cristo (PIO XI, 1937, "Será verdade...", par. 38).ำ

O liberalismo, que já revelava seus dramáticos resultados, exaltava os princípios associados ao livre mercado que constantemente desrespeitavam ou ignoravam os princípios cristãos, enfraquecendo o papel de Estados cujos limites - ou falta de limites de poderes foram historicamente abençoados pela Igreja.

\section{"Remédios" e meios}

A doutrina da Igreja é apresentada como a única apta à salvação contra a ideologia comunista, esse "pernicioso inimigo" (PIO XI, 1937, "IV - Remédios...", par. 39)p da civilização cristã. A renovação espiritual é reclamada como condição para a renovação de adeptos que poderão fazer frente a essa bipolarização sustentada pela Carta. Como ela própria ressaltara, a Igreja permaneceu ausente por muito tempo nas ramificações sociais. Embebeu-se de poderes autocráticos e defendeu-os por ação ou omissão fundada na vontade divina.

A religiosidade de seus fiéis, detecta, se mostra superficial, e sem evolução para a prática dos princípios que a fé católica professa. Invoca o desapego aos bens terrenos, como ferramenta de acalento aos ímpetos revolucionários comunistas próprios de um proletariado alijado por séculos dos prazeres materiais e mesmo da digna subsistência. A promessa de "bem-aventurados os pobres" (PIO XI, 1937, "Desapego dos bens...", par. 44, grifo do autor) ${ }^{a}$ pelo Senhor e de que a felicidade não se encontra na riqueza não se mostraria, assim, capaz de ilidir as propostas comunistas, que aspiravam a terrena satisfação material mínima e solidária, o que os conhecidos excessos da nomenklatura não foram capazes de contaminar, ao menos no plano teórico.

De um lado, havia uma incitação a uma vida mais franciscana:

Para assegurar, pois, a vida eterna, e poder eficazmente socorrer os necessitados, é necessário voltar a uma vida mais modesta; renunciar aos prazeres, muitas vezes até pecaminosos, que o mundo hoje em dia oferece em tanta abundância; esquecerse a si mesmo por amor ao próximo (PIO XI, 1937, "Caridade cristã", par. 48).r

Noutro, dirigiam-se diretamente aos "patrões e industriais cristãos", para que limitassem o exercício do direito de propriedade reconhecido pela Igreja, "por vezes empregado para defraudar o operário de seu justo salário e de seus direitos sociais" (PIO 
XI, 1937, "Deveres de estrita justiça”, par. 50). s Reconhece-se que inexiste justiça social se os trabalhadores não alcançam o necessário para o digno sustento e não se Ihes facilita o ensejo de adquirir uma "modesta fortuna" (PIO XI, 1937, “Justiça Social”, par. 52). ${ }^{\text {É uma }}$ chamada de atenção de que era momento de ceder alguns anéis para impedir o decepar dos dedos.

Proclama Sua Santidade Pio XI que se o modo de proceder de uma fração dos católicos deixou a desejar no campo econômico-social, descortinando palco para doutrinas alternativas ou substitutivas, foi por falta de conhecimento e meditação sobre os ensinamentos pretéritos de todos Sumos Pontífices sobre a temática, reclamando novamente pelas falhas na disseminação dos ensinamentos da lgreja.

Apresenta-se uma atomística ou monopolista visão do DNA da justiça social. Há, para a Igreja, hipocrisia quando "sem renunciarem um ponto a seus perversos princípios, convidam os católicos a colaborar com eles no campo chamado humanitário e caritativo, propondo às vezes, até coisas completamente conformes ao espírito cristão e à doutrina

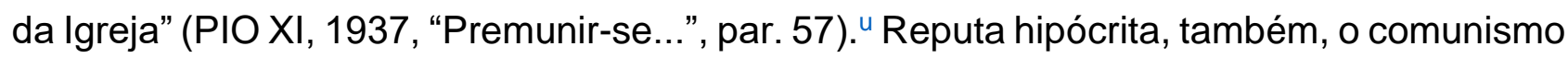
com um aspecto mais brando, não impedindo o culto religioso.

\section{Ministros e auxiliares da obra social da Igreja}

É momento, diante do que considera um sombrio cenário de um mundo sob o espectro do comunismo, de invocar o papel missionário dos sacerdotes, legitimados para esse desiderato da Santa Sé, junto especialmente ao encontro dos operários pobres. Cobra-se, das bases sacerdotais, o exemplo de uma vida virtuosa, o que de modo geral se fez notar essencialmente nas paróquias e nos órgãos de maior contato com o povo.

Não seria uma batalha a ser vencida sozinha. Invoca-se a ação das organizações auxiliares da Igreja, bem como se conclama a adesão das organizações de classe (operários, agricultores, engenheiros, médicos, patrões, intelectuais etc.) "que vivem nas mesmas condições culturais e quase naturalmente se reuniram em agrupamentos homogêneos" (PIO XI, 1937, "Organizações de Classe”, par. 68) $)^{\vee}$ se assim pretendem se manter - numa cruzada contra esse cenário revolucionário. Apela-se ao operariado católico para que seus exemplos sirvam de recondução - exclusiva - à Igreja de seus "irmãos transviados" (PIO XI, 1937, “Apelo aos operários...”, par. 70), ${ }^{\text {w }}$ rogando pela concórdia entre todos os católicos, como forma de prestar incondicional apoio aos "que estão já contagiados ou tocados do mal comunista" (PIO XI, 1937, "Apelo paterno...", par. 80). ${ }^{x}$ 
Nessa missão, encerra-se com socorro ao Estado cristão, que deve ser garantidor da liberdade plena à Igreja, e, além de se aliar com a doutrina católica, dar exemplo de sobriedade administrativa, criar condições materiais de vida, e atingir "efetivamente os que de fato têm nas mãos os maiores capitais e continuamente os vão aumentando com grave prejuízo dos outros" (PIO XI, 1937, "Providências do bem comum", par. 75). y Tais pontos de coincidência com a doutrina socialista e comunista não serviram, no entanto e ao menos no plano formal da Carta, para uma compreensão, mínima que fosse, das razões de origem desse movimento revolucionário.

\section{Considerações finais}

De Dom Hélder Câmara, uma irretocável conclusão paradigmática: "Se dou pão aos pobres, todos me chamam de santo. Se mostro por que os pobres não têm pão, me chamam de comunista e subversivo" (INSTITUTO VLADIMIR HERZOG , [2014?], par. 1). ${ }^{a}$ De fato, a Igreja sempre se centrou na caridade, o que está distante de uma característica negativa. No entanto, essa política, assim resumida, representou uma estagnação que ignorou uma necessidade histórica de sublevação.

A ojeriza bolchevique não residia na espiritualidade e na fé católica pura e simplesmente (ainda que na confusa fase comunista revolucionária assim também se apresentasse), mas no predeterminismo que por séculos acalmara as massas exploradas por monarcas e estados autocráticos, como no caso da Rússia czarista.

De suas entrevistas reveladoras na ex-URSS no período pós-perestroika e glasnost, escutou Svetlana Aleksiévitch (2016, p. 27)a que o tempo todo o ser humano é submetido a escolhas: "a liberdade ou o bem-estar e a ordem na vida; a liberdade com sofrimento ou a felicidade sem liberdade. E a maioria das pessoas escolhe o segundo caminho". O regime comunista bolchevique, em 1937 (ano da Divinis redemptoris), oferecia esse segundo caminho. A crítica de sua não consolidação não anulava o novo horizonte. Séculos de opressão, sem liberdade, sem felicidade e acima de tudo, sem esperanças que não aquelas além da vida ou da vida eterna, serviram de palco para novos bem-aventurados que apontavam soluções terrenas e imediatas para as injustiças vigentes.

Perdeu-se a oportunidade para, com os acertos e desacertos experimentados na história, se positivar a consolidação de meios de aproximação e de extração de objetivos comuns, como forma de impedir a perpetuação da "excomunhão" e a confusão mental ou espiritual daqueles que, sem abandonar as aspirações de uma vida no catolicismo, achem 
nas doutrinas socialistas e comunistas (já reformadas e sem necessariamente abraçar o todo) via de adesão para as soluções das injustiças sociais que seguiam e seguem reinantes.

\section{Referências}

ALEKSIÉVITCH, Svetlana. O fim do homem soviético. São Paulo: Companhia das Letras, 2016. ${ }^{\mathrm{a}}$

INSTITUTO VLADIMIR HERZOG. Dom Hélder Câmara. Memórias da Ditadura, [2014?]. Disponível em: http://memoriasdaditadura.org.br/biografias-da-resistencia/dom-heldercamara/. Acesso em: 7 mar. 2017. ${ }^{a}$

LUXMOORE, Jonathan, BABIUCH, Jolanta. The catolic church and communism, 17891989. Religion, State and Society, v. 27, n. 3-4, p. 301-313, 1999. Cross ${ }^{\text {Ref. a }}$

MARIANI, Bethania. O PCB e a imprensa: os comunistas no imaginário dos jornais: 19221989. Rio de Janeiro: Revan, 1998. ${ }^{a}$

PEREIRA, Marco Antônio Machado Lima. O anticomunismo católico em cena. Revista Nures, n. 11, p. 1-24, jan./abr. 2009. Disponível em: https://revistas.pucsp.br/index.php/nures/article/view/7355/5351. Acesso em: 30 set. 2013. ${ }^{a}$

PIO XI. Divinis redemptoris. 1937. Disponível em: https://w2.vatican.va/content/piusxi/pt/encyclicals/documents/hf_p-xi_enc_19370319_divini-redemptoris.html. Acesso em 2 de jan. 2017. . b, b, c, d, e, f, g, h, i, j, k, I, m, n, o, p, q, r, s, t, u, v, w, x, y

TROELTSCH, Ernest. The social teaching of the christian churches. London: George Allen \& Unwin, 1931. ${ }^{a}$ 